\title{
Performance of Different Size True Potato Seed Seedling Tubers at Khumaltar
}

\author{
Ram C Adhikari \\ Potato Research Program-NARC, Khumaltar-Lalitpur
}

\begin{abstract}
A field study was carried out at Khumaltar-Lalitpur, during 2002-2004 to evaluate and compare the performance of different sizes of seedling tubers (1-5 g, 5-10 g, 10-20 g and 20-40 g) of true potato seed (TPS) with whole and half cut seed tubers of Desiree of 20-40 g size at $60-\times 25-\mathrm{cm}$ spacing. Percent emergence, plant height, ground cover by foliage, stems/plant, number of tubers per plant, marketable and total yields were significantly increased with the increase in seedling tubers weight as compared to whole and half cut seed tubers of Desiree. Late blight (Phytophthora infestans L.) disease was quite low in the TPS crops than Desiree. Both whole and half cut seed tubers of Desiree produced significantly higher average per tuber weight. Uniformity of the tubers harvested from different sizes of seedling tubers was statistically similar and tubers from Desiree were statistically uniform as compared to seedling tubers. The three years result suggests that more than $1 \mathrm{~g}$ size seedling tubers can be successfully used for potato production as from the seed tubers of any standard variety.
\end{abstract}

Key words: Desiree, seedling tuber, tuber size, tuber yield

\section{INTRODUCTION}

It has long been the tradition of majority of farmers in Nepal to use left small seed tubers, and sometimes even slice pieces with only one eye as seed for growing the potato crop to cover large area as much as possible with the minimum input of seed by using smaller seed pieces or very small seed tubers. This practice may be considered as one of the factors responsible for the low productivity. In such situation true potato seed (TPS) are the best with lower seed cost and higher yield potential. By using TPS as planting material about 18 percent of total edible potato production in developing countries can be saved for food (CIP 1982). Moreover viral, bacterial and other plant pathogens can be transmitted through tubers to succeeding generation, subsequently reducing plant health and yield. TPS minimizes both of these limitations, because no portion of the usable harvest needs to be diverted for seed and diseases are much less prevalent in the botanical seed as compared to vegetative propagated materials (Sadik 1983). These factors in TPS are matter of interest especially to resource poor farmers in developing countries like Nepal. Potato propagation by true seed (Wiersema 1986) has resulted in an increasing use of seedling tubers derived from TPS at the farmer's level. TPS is usually used to produce small seedling tubers ( $<20 \mathrm{~g} /$ tubers) that are used as seed to produce a ware potato crop.

High quality first generation seedling tubers (F1C1) can be obtained by seeding TPS in the nursery at high plant density (Nayar 1992, Wiersema 1985, Wiersema 1986) or by planting seedlings directly in the field. In small nursery beds, the adverse conditions can be managed well than in the field. Seedling tubers above $1 \mathrm{~g}$ size can be used for potato production (Adhikari and Rai 2004). Wiersema (1986) reported that the yield increases were significant with $>5 \mathrm{~g}$ size tubers. It has been widely reported that both growth and yield of individual stems are largely dependent on the seed tuber size (Allen and Scoot 1980, Wiersema 1986). 
Generally higher proportion of small size $(<10 \mathrm{~g})$ seedling tubers derived from TPS can be obtained in the nursery at high plant density. So far no systematic study has been done in Nepal to find out the differential yield performance of seedling tubers in terms of size. Thus the present study was undertaken to compare the performance of four grades of seedling tubers, $1-5 \mathrm{~g}, 5-10 \mathrm{~g}, 10-20 \mathrm{~g}$ and 20-40 $\mathrm{g}$ with a seed weight of 20-40 g whole and half cut seed tubers of Desiree.

\section{MATERIALS AND METHODS}

An experiment was carried out during 2002-2004 at Hattiban Research Farm of Potato Research Program, Khumaltar-Lalitpur (1350 masl.). Before starting the experiment, the land was used for growing rice in summer (rainy season). Plants from seedling tubers of different weights (1-5 g, 5-10 g, 10-20 g and 20-40 g) were evaluated and compared with whole and cut half seed tubers of Desiree variety (20-40 g) under partial irrigation condition.

Seedling tubers of TPS family HPS II/67 derived from the nursery beds in the field during 2001, 2002 and 2003 crop seasons at Hattiban Research Farm, were used in the experiment. After harvesting, the graded seedling tubers were kept in cold store till middle of Jan 2002, 2003 and 2004. Seedling tubers and seed tubers of Desiree were taken out from the cold store on 15 January and spread on diffused light store for sprouting. Well sprouted seedling tubers (all sizes), whole and half cut seed tubers of Desiree were planted in the field on 5 Feb 2002, 7 Feb 2003 and Feb 5, 2004. Just before planting, whole tubers of 40-80 g were cut longitudinally to make tuber half of 20-40 g. Randomized complete block design was used with four replications in plot of 3- $\times 2.4-\mathrm{m}$ size consisted of four rows with 12 plants each. Distance between rows was $0.6 \mathrm{~m}$, and spacing between plants was $0.25 \mathrm{~m}$. A basal dose of $\mathrm{N}, \mathrm{P}$ and $\mathrm{K}$ fertilizer was applied at the rate of 50:100:60 kg/ha respectively. Nitrogen was applied through DAP (18:48:00) and urea (46:0:0), phosphorus through di-ammonium phosphate (18:48:0) and potassium through muriate of potash (0:0:60). In addition, farmyard manure (FYM) at the rate of $20 \mathrm{t} / \mathrm{ha}$ was also used in the plots. Additional nitrogen at the rate of $50 \mathrm{~kg} / \mathrm{ha}$ was top-dressed as urea at the time of first earthing-up ie 45 days after planting (DAP). Insecticides and fungicides were not used at all. Weeds were controlled by hand pulling at 45 and 60 DAP.

Measurement on growth parameters such as stem number per hill, percent ground cover, plant height and late blight disease infection at 1-9 scales $(1=$ no symptoms, $2=$ up to $5 \%$ affected, $3=5-15 \%$ affected, $4=15-35 \%$ affected, $5=35-65 \%$ affected, $6=65-85 \%$ affected, $7=85-95 \%$ affected, $8=$ above $95 \%$ affected and $9=$ dead) were taken. Disease severity was estimated weekly and expressed as the fraction of the foliage infected. For accurate determination of stem numbers, the number of stems at soil level (above ground stems) was counted just before hilling. Ground cover by foliage was determined at 60 days after planting using wooden frame of $1 \mathrm{~m}$ by $0.6 \mathrm{~m}$. The frame was divided into $1-\times 1-\mathrm{cm}$ grid cell by double strings (one directly above the other). The frame was placed above two plants and the area below each intersection scored as green (cover by foliage) or not greens (not covered by foliage). Crop raised from true potato seed was dehaulmed after 110 days of planting and harvested 10 days later. Desiree was dehaulmed at 90 days and harvested at 100 days after planting. Tuber germination after 30 days of planting, marketable (fraction $>20 \mathrm{~g}$ size) (Kadian et al 1988) and total tuber yield, number of tuber per hill, average tuber weight and tuber uniformity was recorded at harvesting.

Analysis of variance was performed by MSTATC (1986) to investigate the treatment effects. Duncan Multiple Range Test was used for comparison of means. The data analysis procedures were followed as described by Gomez and Gomez (1984). 


\section{RESULTS AND DISCUSSION}

\section{Field emergence}

Percentage of final emergence was significantly increased with higher seedling tuber weight during 2002 and 2004 (Table 1). Although three years emergence means of plants from seedling tubers size of $>10 \mathrm{~g}$ and whole and half cut seed tubers of Desiree were similar. Emergence was delayed in seedling tuber of 1-5 g. Plants from 1-5 g tubers required an average of 3 days more to reach $90 \%$ emergence than plants from larger tubers. Emergence of 5-10 g seedling tubers was a day later than the larger tubers. Wiersema and Cabello (1986) reported that there was little difference in time to emergence between 5-10 $\mathrm{g}$ tubers and those from larger tubers.

Table 1. Effect of seedling tuber weight, whole and half cut seed tuber of Desiree on plant emergence and plant height at Khumaltar-Lalitpur during 2002-2004

\begin{tabular}{lllllllll}
\hline Tuber weight, $\mathrm{g}$ & \multicolumn{4}{c}{ Emergence, \% } & \multicolumn{3}{c}{ Plant height, cm } \\
\cline { 2 - 9 } & 2002 & 2003 & 2004 & Mean & 2002 & 2003 & 2004 & Mean \\
\hline Seedling tuber 1-5 & $89.50 \mathrm{~b}$ & 93.13 & $87.50 \mathrm{c}$ & $90.04 \mathrm{~b}$ & $49.10 \mathrm{~b}$ & $44.30 \mathrm{~b}$ & $51.90 \mathrm{~b}$ & $48.43 \mathrm{c}$ \\
Seedling tuber 5-10 & $95.00 \mathrm{a}$ & 94.38 & $90.00 \mathrm{bc}$ & $93.13 \mathrm{~b}$ & $50.55 \mathrm{~b}$ & $49.80 \mathrm{a}$ & $52.05 \mathrm{~b}$ & $50.80 \mathrm{~b}$ \\
Seedling tuber 10-20 & $98.75 \mathrm{a}$ & 96.25 & $95.00 \mathrm{~b}$ & $96.67 \mathrm{a}$ & $52.15 \mathrm{~b}$ & $50.90 \mathrm{a}$ & $53.90 \mathrm{~b}$ & $52.30 \mathrm{~b}$ \\
Seedling tuber 20-40 & $100.00 \mathrm{a}$ & 100.00 & $98.33 \mathrm{a}$ & $99.44 \mathrm{a}$ & $57.15 \mathrm{a}$ & $53.00 \mathrm{a}$ & $58.80 \mathrm{a}$ & $56.32 \mathrm{a}$ \\
Desiree whole seed 20-40 & $100.00 \mathrm{a}$ & 100.00 & $99.17 \mathrm{a}$ & $99.72 \mathrm{a}$ & $53.75 \mathrm{a}$ & $44.25 \mathrm{~b}$ & $51.50 \mathrm{c}$ & $49.68 \mathrm{~d}$ \\
Desiree half cut seed 20-40 & $98.75 \mathrm{a}$ & 98.75 & $99.17 \mathrm{a}$ & 98.89 & $53.00 \mathrm{ab}$ & $43.80 \mathrm{c}$ & $49.90 \mathrm{~d}$ & $48.90 \mathrm{e}$ \\
\hline CV, \% & 5.38 & 4.16 & 3.15 & 4.10 & 4.75 & 4.71 & 3.51 & 4.42 \\
F test & $* *$ & ns & $* *$ & $* *$ & $* *$ & $* *$ & $* *$ & $* *$ \\
\hline
\end{tabular}

** Significant difference at $1 \%$ level. ns, Non significant. Means followed by the same letter within columns are not significantly different according to Duncan's Multiple Range Test at $P=0.05$.

\section{Plant height}

Plant height increased with increasing seedling tuber weight in all the years (Table 1). Considerable differences were seen in the height of plant from seedling tubers and whole and half cut seed tubers of Desiree. Maximum mean plant height $(56.32 \mathrm{~cm}$ ) was recorded where seedling tubers of $20-40 \mathrm{~g}$ were planted. Batra et al (1992) also reported increase in plant height with the increase in seedling tuber weight. Plants from 5-10 g and 10-20 g seedling tubers had statistically similar plant height but the plants from whole and half cut seed tuber of Desiree were significantly taller than plants from 1-5 g size seedling tubers. The variation in plant height may be due to food reserve for early growth of seed tubers and varietal characters and interactions of planting materials and environment. Wiersema (1986) and Batra et al (1992) have reported similar findings.

Table 2. Effect of seedling tuber weight, whole and half cut seed tuber of Desiree on ground cover and late blight infection at Khumaltar-Lalitpur during 2002-2004

\begin{tabular}{lllllllll}
\hline Tuber weight, $\mathrm{g}$ & \multicolumn{3}{c}{ Ground cover, $\%$} & \multicolumn{3}{c}{ Late blight infection, 1-9 scales } \\
\cline { 2 - 9 } & 2002 & 2003 & 2004 & Mean & 2002 & 2003 & 2004 & Mean \\
\hline Seedling tuber 1-5 & $59.75 \mathrm{c}$ & $67.50 \mathrm{~b}$ & $60.25 \mathrm{~b}$ & $62.50 \mathrm{c}$ & $2.00 \mathrm{~b}$ & 3.00 & $2.00 \mathrm{~b}$ & $2.33 \mathrm{~b}$ \\
Seedling tuber 5-10 & $66.75 \mathrm{~b}$ & $75.00 \mathrm{a}$ & $67.25 \mathrm{a}$ & $69.67 \mathrm{~b}$ & $2.00 \mathrm{~b}$ & 3.00 & $2.00 \mathrm{~b}$ & $2.33 \mathrm{~b}$ \\
Seedling tuber 10-20 & $77.50 \mathrm{a}$ & $77.50 \mathrm{a}$ & $66.50 \mathrm{a}$ & $73.83 \mathrm{a}$ & $2.00 \mathrm{~b}$ & 3.00 & $2.00 \mathrm{~b}$ & $2.33 \mathrm{~b}$ \\
Seedling tuber 20-40 & $80.50 \mathrm{a}$ & $78.75 \mathrm{a}$ & $70.00 \mathrm{a}$ & $76.42 \mathrm{a}$ & $2.00 \mathrm{~b}$ & 3.00 & $2.00 \mathrm{~b}$ & $2.33 \mathrm{~b}$ \\
Desiree whole seed 20-40 & $63.00 \mathrm{bc}$ & $57.50 \mathrm{c}$ & $60.25 \mathrm{~b}$ & $60.25 \mathrm{~cd}$ & $7.00 \mathrm{a}$ & 6.00 & $4.00 \mathrm{a}$ & $5.67 \mathrm{a}$ \\
Desiree half cut seed 20-40 & $62.50 \mathrm{bc}$ & $52.50 \mathrm{c}$ & $57.75 \mathrm{~b}$ & $57.58 \mathrm{~d}$ & $7.00 \mathrm{a}$ & 6.00 & $4.00 \mathrm{a}$ & $5.67 \mathrm{a}$ \\
\hline CV, \% & 4.57 & 5.88 & 5.27 & 5.27 & 10.47 & 12.31 & 11.48 & 11.70 \\
F test & $* *$ & $* *$ & $* *$ & $* *$ & $* *$ & $* *$ & $* *$ & $* *$ \\
\hline
\end{tabular}

** Significant difference at $1 \%$ level. Means followed by the same letter within column are not significantly different according to Duncan's Multiple Range Test at $P=0.05$. 


\section{Ground cover}

The ground covers by foliage among the treatments were statistically significant in all the years. The mean ground cover by foliage of three years showed that 20-40 g size seedling tubers had the maximum ground cover (76.42\%), whereas minimum in half cut seed tubers of Desiree (57.58\%) (Table 2). Plants from 10-20 g and 20-40 $\mathrm{g}$ had statistically similar ground cover. This may be due to emergence and plant height (Table 1).

Ground cover by foliage indicates the size of the photosynthetic system and is therefore an indication of intercepted radiation (Kloos 1986). Allen and Scoot (1980) have shown that there is a close relationship between total intercepted light and tuber yield. Ground cover by foliage was significantly increased with increasing seedling tuber weight and number of stems per plant (Tables 2, 3). In general greater the number of stems, the earlier the ground cover by foliage. Lateral stems on the main stem near or in the ground cover can help to achieve a close canopy and so enhance light interception. This suggest a positive effect of the amount of tuber reserve per stem on plant growth at early stage which is also reported by Moorby (1967), Wiersema (1986), Iritani et al (1972).

\section{Late blight infection}

Late blight incidence recorded in the 1-9 scales indicated that diseases build up in the seedling tubers was significantly lower than whole and cut seed tuber of Desiree (Table 2). Late blight infection in the treatments was slightly higher in 2003 as compared to 2002 and 2004. The variation in late blight infection may be due to the not conducive environment in 2003 for late blight pathogens (Table 2). TPS seedling tubers represent genetic variability, which are genetically not uniform and hence each plant acted as different genotype, which needed different matching race of Phytophthora infestans L. Under such situation accumulation of higher genes of virulence by a pathogen become difficult. This phenomenon not only delayed the infection but also check the build up of late blight. Singh and Bahal (1997) also indicated that disease build up in the TPS crops were lower than the clonal variety Rose through seed tubers of variety Kufri Jyoti.

Table 3. Effect of seedling tuber weight, whole and half cut seed tuber of Desiree on number of main stems per plant and number of tubers per plant at Khumaltar-Lalitpur during 2002-2004

\begin{tabular}{lllllllll}
\hline Tuber weight, $\mathrm{g}$ & \multicolumn{3}{c}{ Number of main stems/plant } & \multicolumn{3}{c}{ Number of tubers/plant } \\
\cline { 2 - 9 } & 2002 & 2003 & 2004 & Mean & 2002 & 2003 & 2004 & Mean \\
\hline Seedling tuber 1-5 & $2.45 \mathrm{~d}$ & $1.65 \mathrm{~d}$ & $2.80 \mathrm{~d}$ & $2.30 \mathrm{e}$ & $10.82 \mathrm{c}$ & $11.08 \mathrm{~b}$ & $7.16 \mathrm{~cd}$ & $9.68 \mathrm{~d}$ \\
Seedling tuber 5-10 & $3.30 \mathrm{c}$ & $1.85 \mathrm{~d}$ & $3.00 \mathrm{c}$ & $2.72 \mathrm{c}$ & $10.81 \mathrm{c}$ & $13.58 \mathrm{a}$ & $7.68 \mathrm{c}$ & $10.69 \mathrm{c}$ \\
Seedling tuber 10-20 & $3.55 \mathrm{~b}$ & $2.25 \mathrm{c}$ & $3.50 \mathrm{~b}$ & $3.10 \mathrm{~b}$ & $12.43 \mathrm{~b}$ & $13.77 \mathrm{a}$ & $9.35 \mathrm{~b}$ & $11.85 \mathrm{~b}$ \\
Seedling tuber 20-40 & $3.80 \mathrm{a}$ & $2.60 \mathrm{~b}$ & $3.70 \mathrm{a}$ & $3.37 \mathrm{a}$ & $14.35 \mathrm{a}$ & $13.82 \mathrm{a}$ & $10.11 \mathrm{a}$ & $12.76 \mathrm{a}$ \\
Desiree whole seed 20-40 & $2.50 \mathrm{~d}$ & $2.95 \mathrm{a}$ & $3.10 \mathrm{c}$ & $2.85 \mathrm{c}$ & $6.66 \mathrm{~d}$ & $8.03 \mathrm{c}$ & $6.74 \mathrm{de}$ & $7.14 \mathrm{e}$ \\
Desiree half cut seed 20-40 & $2.35 \mathrm{~d}$ & $2.35 \mathrm{c}$ & $2.80 \mathrm{~d}$ & $2.50 \mathrm{~d}$ & $6.15 \mathrm{~d}$ & $7.04 \mathrm{~d}$ & $6.17 \mathrm{e}$ & $6.45 \mathrm{e}$ \\
\hline CV, \% & 4.92 & 6.95 & 3.24 & 4.92 & 4.03 & 4.81 & 6.08 & 4.91 \\
F test & $* *$ & $* *$ & $* *$ & $* *$ & $* *$ & $* *$ & $* *$ & $* *$ \\
\hline
\end{tabular}

** Significant difference at $1 \%$ level. Means followed by the same letter within column are not significantly different according to Duncan's Multiple Range Test at $P=0.05$.

\section{Stem number}

If high yields per plant are desired, stems/plant should be low, where as it should be high when high yields per hectare are required (Beukema and Van Der Zaag 1990). The number of stem per plant increased with increasing seedling tuber weight (Table 3). It is attributed to increase in number of eyes. Batra et al (1992) and Iritani et al (1972) also reported increase in stems per plant with increases in seed size. The maximum stems/plant (3.37) was recorded in plants from seedling tubers $20-40 \mathrm{~g}$ size and minimum in 1-5 g seedling tubers. Plants from whole seed tubers of Desiree produced significantly 
higher stems/plant due to higher eyes in the tubers. In all the sizes of seedling tubers stems/plant was lower in 2003 as compared to 2002 and 2004.

\section{Tuber number}

Tuber number is a function of stem population (Cho and Iritani 1983), but is also influenced by cultivars and several other factors, which control vegetative growth. There was significant effect of tuber sizes on tuber number per plant in all the years (Table 3). All the sizes of seedling tubers produced significantly higher tuber per plant compared to whole and half-cut seed tubers of Desiree. Tuber numbers per plant were not consistent across years. Tubers/plant was similar in 2002 and 2003 but it was low in 2004 due to unavailability of irrigation during growth period in 2004. TPS seedling tubers have tendency to produce more number of tubers per plant than Desiree seed tubers. The three years mean showed that plants from whole and cut seed pieces of Desiree produced similar tuber number per plant. Plants from increasing weight of seedling tubers significantly increased the tuber number per plant. This result agree with the data from Batra et al (1992) indicated that tuber number per plant increased with increase in seedling tuber size. The highest tuber number per plant was recorded in 20-40 g size seedling tuber planted crop. The data indicate that the number of main stems per plant has positive bearing on number of tubers per plant. The results corroborate with the findings of Wiersema (1986) and Kadian et al (1988).

Table 4. Effect of seedling tuber weight, whole and half cut seed tuber of Desiree on marketable yield and total yield at Khumaltar-Lalitpur during 2002-2004

\begin{tabular}{lllllllll}
\hline Tuber weight, g & \multicolumn{3}{c}{ Marketable yield, $\mathrm{t} / \mathrm{ha}(>20 \mathrm{~g})$} & \multicolumn{4}{c}{ Total yield t/ha } \\
\cline { 2 - 9 } & 2002 & 2003 & 2004 & Mean & 2002 & 2003 & 2004 & Mean \\
\hline Seedling tuber 1-5 & $21.93 \mathrm{c}$ & $21.07 \mathrm{c}$ & $11.50 \mathrm{e}$ & $18.17 \mathrm{~d}$ & $24.90 \mathrm{~cd}$ & $24.24 \mathrm{c}$ & $13.28 \mathrm{~d}$ & $22.82 \mathrm{~d}$ \\
Seedling tuber 5-10 & $23.33 \mathrm{bc}$ & $24.62 \mathrm{~b}$ & $15.28 \mathrm{c}$ & $21.08 \mathrm{c}$ & $26.60 \mathrm{c}$ & $28.14 \mathrm{~b}$ & $17.18 \mathrm{c}$ & $23.97 \mathrm{c}$ \\
Seedling tuber 10-20 & $24.11 \mathrm{~b}$ & $26.83 \mathrm{ab}$ & $19.28 \mathrm{~b}$ & $23.41 \mathrm{~b}$ & $28.81 \mathrm{~b}$ & $30.67 \mathrm{a}$ & $21.45 \mathrm{~b}$ & $26.98 \mathrm{~b}$ \\
Seedling tuber 20-40 & $31.45 \mathrm{a}$ & $27.51 \mathrm{a}$ & $22.45 \mathrm{a}$ & $27.14 \mathrm{a}$ & $37.17 \mathrm{a}$ & $30.85 \mathrm{a}$ & $24.78 \mathrm{a}$ & $30.93 \mathrm{a}$ \\
Desiree whole seed 20-40 & $24.01 \mathrm{~b}$ & $16.83 \mathrm{~d}$ & $13.63 \mathrm{~d}$ & $18.16 \mathrm{~d}$ & $25.13 \mathrm{~cd}$ & $18.13 \mathrm{~d}$ & $14.78 \mathrm{~d}$ & $19.35 \mathrm{e}$ \\
Desiree half cut seed 20-40 & $22.03 \mathrm{c}$ & $14.76 \mathrm{~d}$ & $13.00 \mathrm{~d}$ & $16.60 \mathrm{e}$ & $23.44 \mathrm{~d}$ & $15.84 \mathrm{~d}$ & $14.55 \mathrm{~d}$ & $17.94 \mathrm{f}$ \\
\hline CV, \% & 4.42 & 7.55 & 6.09 & 6.12 & 4.33 & 4.67 & 5.78 & 5.62 \\
F test & $* *$ & $* *$ & $* *$ & $* *$ & $* *$ & $* *$ & $* *$ & $* *$
\end{tabular}

** Significant difference at 1\% level. Means followed by the same letter within columns are not significantly different according to Duncan's Multiple Range Test at $P=0.05$.

\section{Tuber yield}

Weight of the TPS seedling tubers, whole and half-cut seed tubers of Desiree significantly affected the total and marketable tuber yields per hectare in all years (Table 4). The significantly maximum total and marketable $(>20 \mathrm{~g})$ tuber yield was obtained when larger seedling tubers were planted. Seedling tuber 20-40 g size produced the highest total and marketable yield (30.93 t/ha and $27.14 \mathrm{t} / \mathrm{ha}$, respectively). The overall performance of three years means showed that relative yield difference between plants grown from all the sizes of seedling tubers was greater than whole and half cut seed tubers. This may be explained on the basis of photosynthates in large size seedling tubers that helped in early emergence, better growth, high ground cover by foliage, tubers/plant and positive effect on the amount of tuber reserve per stem on growth (Tables 1, 2, 3). The results are in conformity with the findings of Wiersema (1986), Kadian et al (1988) and Iritani et al (1972). The data presented in Table 4 indicate the production of marketable and total tuber weight was high in 2002 and 2003 as compared to 2004 probably due to unavailability of irrigation in the early bulking stage. The yield of whole and half cut seed tubers of Desiree is higher in 2002 the 2003 and 2004. The variation may be due to better haulm growth and average tuber weight (Tables 2, 5). The whole seed tuber of Desiree produced statistically higher marketable and total yields in 2002 than half-cut seed tuber of Desiree. But it was similar in 2003 and 2004. In most of the developing countries especially in Nepal the tuber size of $20 \mathrm{~g}$ and above is 
usually accepted as marketable. The seedling tuber size less than $20 \mathrm{~g}$ can successfully be used as seed tubers for next season planting which would give the same potential yield from seed tubers of standard variety.

Table 5. Effect of seedling tuber weight, whole and half cut seed tuber of Desiree on average tuber weight and tuber uniformity at Khumaltar, Lalitpur during 2002-2004

\begin{tabular}{lllllllll}
\hline Tuber weight, g & \multicolumn{3}{c}{ Average tuber weight, $\mathrm{g}$} & \multicolumn{3}{c}{ Tuber uniformity, 1-5 scales } \\
\cline { 2 - 9 } & 2002 & 2003 & 2004 & Mean & 2002 & 2003 & 2004 & Mean \\
\hline Seedling tuber 1-5 & $34.31 \mathrm{~cd}$ & 31.14 & $27.80 \mathrm{~d}$ & $31.08 \mathrm{c}$ & $4.00 \mathrm{c}$ & $4.00 \mathrm{~b}$ & $4.00 \mathrm{c}$ & $4.0 \mathrm{~b}$ \\
Seedling tuber 5-10 & $36.88 \mathrm{~cd}$ & 32.94 & $33.56 \mathrm{bc}$ & $34.46 \mathrm{c}$ & $4.00 \mathrm{c}$ & $4.00 \mathrm{~b}$ & $4.00 \mathrm{c}$ & $4.0 \mathrm{~b}$ \\
Seedling tuber 10-20 & $34.80 \mathrm{~d}$ & 33.46 & $34.45 \mathrm{abc}$ & $34.24 \mathrm{c}$ & $4.00 \mathrm{~b}$ & $4.00 \mathrm{~b}$ & $4.00 \mathrm{~b}$ & $4.0 \mathrm{~b}$ \\
Seedling tuber 20-40 & $38.90 \mathrm{c}$ & 33.51 & $36.88 \mathrm{a}$ & $36.43 \mathrm{~b}$ & $4.00 \mathrm{~b}$ & $4.00 \mathrm{~b}$ & $4.00 \mathrm{~b}$ & $4.0 \mathrm{~b}$ \\
Desiree whole seed 20-40 & $61.27 \mathrm{a}$ & 33.96 & $36.00 \mathrm{ab}$ & $43.74 \mathrm{a}$ & $5.00 \mathrm{a}$ & $5.00 \mathrm{a}$ & $4.80 \mathrm{a}$ & $4.93 \mathrm{a}$ \\
Desiree half cut seed 20-40 & $52.91 \mathrm{~b}$ & 33.76 & $32.55 \mathrm{c}$ & $39.74 \mathrm{a}$ & $5.00 \mathrm{a}$ & $5.00 \mathrm{a}$ & $4.80 \mathrm{a}$ & $4.93 \mathrm{a}$ \\
\hline CV, \% & 5.47 & 8.06 & 5.02 & 6.22 & 2.63 & 4.67 & 2.67 & 3.43 \\
F test & $* *$ & ns & $* *$ & $* *$ & $* *$ & $* *$ & $* *$ & $*$ \\
\hline
\end{tabular}

** Significant difference at $1 \%$ level. ns, Non significant. Means followed by the same letter within columns are not significantly different according to Duncan's Multiple Range Test at $P=0.05$. Tuber uniformity scales: $1=$ least uniform and $5=$ Most uniform.

The overall three years mean showed that average tuber weight from all the sizes of seedling tubers was statistically lowest as compared to the whole and half-cut seed tubers of Desiree (Table 5). The average tuber weight among the treatments was significantly different in 2002 and 2004 and insignificant in 2003. Tuber weights of $1-5 \mathrm{~g}, 510 \mathrm{~g}, 10-20 \mathrm{~g}$ seedling tubers were statistically similar. Whole seed tubers of Desiree gave highest average tuber weight $(43.74 \mathrm{~g})$ followed by half cut seed tuber of Desiree (39.74 g) and 20-40 g seedling tubers (36.43 g) and minimum in 1-5 g size (31.08 g). Kadian et al (1988) also reported similar results. Short duration (90 days) Desiree matured earlier than crops grown from TPS seedling tubers. Although no systematic ratings on maturity were taken, it was observed that plants from smaller seedling tubers mature later than the larger. This may explain the average tuber weight differences between plants from the different seedling tuber weights.

The produce from the four sizes of seedling tubers could not be distinguished morphologically in terms of tuber shape, color and depth of eye but statistically distinguished from seed tuber of Desiree (Table 5). The tuber of Desiree was most uniform in color, shape and size compared to seedlings and seedling tubers.

Seedling tubers of TPS family HPS II/67 have shown the potential of giving significantly higher yield of potatoes than Desiree. In Mid Hill condition like Kathmandu valley, the cost of seed tubers is high and good quality disease free seed tubers are not easily available at reasonable cost. Hence, use of above $1 \mathrm{~g}$ size seedling tubers can successfully be used for potato production as from the seed tubers of release cultivars.

\section{ACKNOWLEDGEMENTS}

The author is grateful to GP Rai, Coordinator, Potato Research Program, Khumaltar for constant support for conducting the experiment. KC Upreti, D Chaudhary and YK Shrestha are also thankful for their assistance in conducting the experiment. 


\section{REFERENCES}

Adhikari RC and GP Rai. 2004. Comparative study of seedlings and seedling tubers derived from true potato seed. Paper presented in the fourth national conference on science and technology held at Kathmandu during April 23-26.

Allen EJ and RK Scoot. 1980. An analysis of growth of potato crop. Journal of Agriculture Science, Camb. 94:583-608.

Batra VK, YS Malik and ML Pandita. 1992. Effect of growth regulators on establishment of potato seedlings in relation to seedling tuber production. J. Indian Potato Assoc. 19:17-20.

Beukema HP and DE. Vander Zaag. 1990. Introduction to potato production. Pudock Wageningen. 208 p.

Cho J and WH Iritani. 1983. Comparison of growth and yield of Russet Burbank for a two year period. American Potato Journal 60(8):569-576.

CIP. 1982. World potato facts. International Potato Center (CIP), Lima-Peru. P. 54.

Gomez KA and A Gomez. 1984. Statistical procedure for agricultural research. 2nd eds. John Willy and Sons, New York. Pp. 680.

Iritani WM, R Thorton, L Welter and O Leavy. 1972. Relationships of seed size, spacing, stem numbers to yields of Russet Burbank potatoes. American Potato Journal 40:463-479.

Kadian MS, PK Patel, KC Thakur and MD Upadhaya. 1988. Comparative yield potential of seedling tuberlets from true potato seed in Dessa (Gujarat). J. Indian Potato Assoc. 15: 68-73.

Kloos JP. 1986. Nitrogen and phosphorous requirements for potato production on adtuyon clay in Bukidnon. Philippines Agriculturist 69:251-262.

Moorby J. 1967. Inter stem and inter tuber competition in potatoes. European Potato Journal 10:189-205.

MSTATC. 1986. A microcomputers program for the design, management and analysis of agronomic research experiments. East Lansing, Michigan State University, USA.

Nayar NM. 1992. TPS (True Potato Seed) in India: A critique. J. Indian Potato Assoc. 19 (3-4):93-103.

Sadik S. 1983. Potato production from true seed - present and future. In: Proceedings International Congress "Research for the potato in the year 2000" (WS Hooker, ed). International Potato Center, Lima-Peru. Pp. 19.

Singh K and VK Bahal. 1997. Performance of TPS families for ware potato production in Northeast hills. J. Indian Potato Assoc. 24(3 \& 4):148-153.

Wiersema SG and K Cabello. 1986. Comparative performance of different sized seed tubers derived from true potato seed. American Potato Journal 63(3):241-250.

Wiersema SG. 1985. Production and utilization of seed tubers derived from true potato seed. In: Report of the planning conference on "Innovative methods for propagating potatoes". International Potato Center, LimaPeru. Pp. 95-116.

Wiersema SG. 1986. A method of producing seed tubers from true potato seed. Potato Research 29:225-237. 